\title{
PRESENCE OF HEAVY METALS (LEAD AND CADMIUM) IN MEAT SAMPLED FROM THE TAMALE ABATTOIR AND RISK ASSESSMENT
}

\author{
${ }^{1 *}$ Boahene, P., ${ }^{1}$ Imoro, Z. A., ${ }^{1}$ Cobbina, S. J., ${ }^{2}$ Akpabey, F. J., ${ }^{3,1}$ Ofori, S. A. \\ ${ }^{\mathbf{1}}$ Faculty of Natural Resources and Environment, University for Development Studies, Tamale, Ghana \\ ${ }^{2}$ Water Research Institute, Centre for Scientific and Industrial Research, Tamale, Ghana \\ ${ }^{3}$ Département de Biologie des Organismes, Faculté des Sciences, Université Libre de Bruxelles, Brussels, Belgium \\ *Corresponding author's email: boahenep25@gmail.com
}

\begin{abstract}
The study investigated the presence and concentration of possible heavy metals residues in meat processed at Tamale abattoir. A total of twenty-seven (27) animal parts (liver, kidney and muscles) from goats, sheep and cattle were sampled and analysed for heavy metals using the Graphite Furnace Atomic Absorption Spectrophotometer (GFAAS). Means and standard deviations of $\mathrm{Pb}$ and $\mathrm{Cd}$ concentrations were computed from the data collected to test for the difference in heavy metal concentrations in the various meat samples. Liver samples from all three different animals were found to contain the highest concentration of $\mathrm{Pb}(3.17 \pm 2.39 \mathrm{mg} / \mathrm{kg})$ and $\mathrm{Cd}(3.47 \pm 3.19$ $m g / k g)$. The sampled muscles of all animals used had an average Cd concentration above the permissible. Pb concentrations in cattle and sheep were found to be higher than the permissible limits indicated by the World Health Organisation and United States Environmental Protection Agency. The average daily dose (ADD) of Pb exposure to humans via ingestion were $7.64 \times 10^{-9}-2.19 \times 10^{-8}$ for children and $3.27-9.35 \times 10^{-9}$ for adults. For Cd, the ADD were $1.96-4.57 \times 10^{-6}$ for children and $1.13-2.63 \times 10^{-7}$ for adults. Human health risk assessment proved no eminent risk of carcinogenicity to consumers, but it is estimated that the higher levels of Pb and $\mathrm{Cd}$ in the meat samples may pose a potential health risk over a period of continual exposure.
\end{abstract}

Keywords: Heavy Metals, Kidney, Liver, Muscle, Abattoir

\section{Introduction}

Humans obtain nourishment from meat and meat products due to its large store of micronutrients (Lukáčová et al., 2014). Meat is necessary for body building, repairs, antibodies production and the overall wellbeing of the individual (Ubwa et al., 2017). However, meat and meat products can be compromised by heavy metal contamination. Heavy metals are regarded as a serious health threat due to their toxicity, bioaccumulation, and biomagnification characteristic in food chains (Baykov et al., 1996). Humans are exposed to heavy metals mostly through food. It affects the safety of food and poses health risks to humans even at a low concentration (Rowland \& McKinstry, 2006; Santhi et al., 2008). It appears to be of international interest and various institutions concerned appear to be overwhelmed by the cause and effect of metals in flesh and blood of animals (WHO, 1997).

Sedki et al. (2003) reported that there is deposition of heavy metal residue in meat and meat products we eat. Heavy metal contaminated grasses are one source of heavy metals in meat (Arora et al., 2008). Poor processing of meat in a production line may also introduce heavy metals (Brito et al., 2005). These include singeing off hairs of animals in fuels such as wood mixed with refuse and tires of vehicles (Okiei et al., 2009). At the Tamale abattoir, it is common to identify that a number of butchers use lorry tires as well as fuelwood as singeing materials. 
The main aim of this research was to assess the concentration levels of some heavy metals that may have chanced in the meat from the abattoir and further conduct a health risk assessment on the possible risks of cancer posed to the humans who patronise the meat from the abattoir.

\section{Materials and Methods}

\section{Study Area}

The study was conducted in the Tamale abattoir which is located in the Tamale Metropolis. The Metropolis is located in the Northern Region of Ghana and has a total estimated land size of 646.902 $\mathrm{km}^{2}$ (GSS, 2014). Geographically, the metropolis is located between latitude $09^{\circ} 16$ and $09^{\circ} 34$ North and longitude $00^{\circ} 57$ West (GSS, 2014). There are 115 communities in the Metropolis (GSS, 2014). Majority of the communities in the rural areas have a large area of land which are allocated for agriculture, thus serving as a major food source for the Metropolis. The population of the Metropolis according to the 2010 population and housing census was 537,986 (GSS, 2014).

\section{Sample collection}

Meat samples were collected from the Tamale Abattoir for a period of eight weeks. Locally reared cattle, sheep and goats were selected for this study. For each of the animals selected, three samples of each body parts (liver, kidney and muscles) were randomly sampled, making a total of 27 body parts samples. Samples were carefully packed into sterilized well labelled zip-lock bags and transported to the laboratory in a well-insulated iced box for heavy metal analysis.

\section{Sample preparation}

Samples were washed with deionized water to remove adsorbed particulates and then slightly sun dried under the cover of sterilized beakers for an hour. They were subsequently oven-dried at $105{ }^{\circ} \mathrm{C}$ for three hours to obtain constant weight. Dried samples were ground using an acid pre-washed mortar and pestle. Approximately $2 \mathrm{~g}$ subsample of each sample was prepared for acid digestion using $10 \mathrm{~mL}$ concentration of $\mathrm{HNO}_{3}$ and $\mathrm{HCLO}_{4}$ acids to identify $\mathrm{Pb}$ and $\mathrm{Cd}$ residues in the digested samples.

Analysis of samples for heavy metals

After acid digestion, the samples were analysed for the determination of the levels of potential heavy metal residues using the Graphite Furnace Atomic Absorption Spectrophotometer (GFAAS, Analykjena 400P, Germany).

\section{Human Health risk assessment \\ Exposure assessment}

To assess the exposure of the human population to the presence of $\mathrm{Pb}$ and $\mathrm{Cd}$ present in the meat samples, the main route of exposure considered was ingestion. The average daily dose (ADD) via ingestion was calculated using the following equation (Ying et al., 2016).

$$
\mathrm{ADD}_{\text {ing }}=\mathrm{C}_{\text {food }} \times \frac{\mathrm{IngR}^{\times} \mathrm{EF}^{\times} \mathrm{ED}}{\mathrm{BW}^{\times} \mathrm{AT}} \times 10^{-6}
$$

Where $\mathrm{ADD}_{\text {ing }}$ is Average Daily Dose via Ingestion, $\mathrm{C}_{\text {food }}$ is the Concentration of heavy metal in food, IngR is Ingestion Rate, EF is Exposure Frequency, ED is Exposure Duration, BW is the Body Weight of average individual, AT is the Average Time.

\section{Carcinogenic risk assessment}

The carcinogenic risk describes the possible risks of cancer posed to an individual after ingesting the contaminated meat over a lifetime. The equation for determining the lifetime carcinogenic risk for $\mathrm{Pb}$ according to USEPA (1989) is stated as:

Risk $=\mathrm{ADD} \times \mathrm{SF}$

Where SF $($ Slope Factor $)=8.5 \times 10^{-3}$ for $\mathrm{Pb}$ (USEPA, 2011) 
Table 1 Definition of factors and values for calculating ADD of heavy metals

FACTORS

$\mathrm{C}_{\text {food }}$

IngR

EF

ED

BW

AT
DEFINITION

Concentration of heavy metal in food

Ingestion rate

Exposure frequency

Exposure duration

Body weight

Average time

\section{CHILDREN}

ADULT

$\begin{array}{cc}200 \mathrm{mg} / \text { day } & 100 \mathrm{mg} / \text { day } \\ 350 \text { days } & 350 \text { days } \\ 6 \text { years } & 24 \text { years } \\ 15 \mathrm{~kg} & 70 \mathrm{~kg} \\ 365 \times \mathrm{ED} \text { (days) } & 365^{\times} \mathrm{ED} \text { (days) }\end{array}$

Source: Ying et al. (2016)

Where $\mathrm{IngR}$ is Ingestion rate, $\mathrm{EF}$ is exposure frequency, $\mathrm{ED}$ is exposure duration, $\mathrm{BW}$ is body weight, and AT is average time.

\section{Data analysis}

Mean and standard deviation values of heavy metals concentration in meat samples were computed using GenStat software (version 4.10.3). The results are presented in tables.

\section{Results and Discussion}

Out of the 27 meat parts that were analysed, $\mathrm{Pb}$ was detected in the liver parts of cattle and sheep samples. It can be said that environmental media such as soil could be a contributing factor to the presence of $\mathrm{Pb}$ in the liver parts of the sampled cattle and sheep. This is because of the possible transfer of heavy metals and some trace elements from soil plants to the grazing animals via ingestion (Khalufalla et al., 2011).

In the case of $\mathrm{Cd}$, it was found present in all samples except for goat muscles. Its concentrations in the liver and kidney of all animals were above that reported by Akan et al. (2010) in their study on distribution of heavy metals in the same set of animals. Levels of $\mathrm{Cd}$ and $\mathrm{Pb}$ reported in this study were higher than the findings of Nkansah and Ansah (2014) who also determined the levels of $\mathrm{Pb}$ and $\mathrm{Cd}$ in the same animal parts used in this research.
The risk of eating $\mathrm{Cd}$ contaminated grasses for the animals is higher at places where farmlands are fertilized with phosphate fertilizers and free-range grazing by livestock is the most practiced system (Smolders \& Six, 2013). Unfortunately, this is the case in Tamale making this source of contamination very likely. It is therefore relevant to note that controlling of animals' feeding will be relevant in reducing heavy metal concentration in animals (Sabir et al., 2003).

In general, the detection of $\mathrm{Pb}$ and $\mathrm{Cd}$ in the meat samples could be associated with the use of plastics, lorry tires and engine oil and sometimes wood for singeing of meat. These materials are known to contain toxic substances such as dioxin, polycyclic aromatic hydrocarbons, benzenes and heavy metals which are able to enter into the tissues of these animals due to their high lipophilic ability (Ekanma $\&$ Ottah, 2015). Moreover, the improper ways of washing singed animals can also leave deposits of contaminants including these heavy metals on muscles, liver, and kidney (Obiri- Danso et al., 2008; Ekanma \& Ottah, 2015).

High concentration of $\mathrm{Cd}$ in the sheep meat samples could be attributed to continuous feeding on contaminated food sources because the extent of exposure to the inorganic contaminant $(\mathrm{Pb}$ and $\mathrm{Cd})$ causes an increase in the accumulation of heavy 
metals in especially the liver and kidney of the animal (Gašparík et al., 2016).

High concentrations of $\mathrm{Pb}$ and $\mathrm{Cd}$ when ingested by humans through the consumption of contaminated meat can cause acute or chronic effects such as loss of appetite, abdominal pain, renal dysfunction, kidney damage and death to humans (Martin \& Griswold, 2009; Chakraborty et al., 2013).

Table 2 Lead $(\mathrm{Pb})$ and Cadmium (Cd) concentrations in liver, muscle, and kidney

\begin{tabular}{ccc}
\hline Organs & $\begin{array}{c}\mathrm{Pb} \\
\text { Concentration } \\
(\mathrm{mg} / \mathrm{kg})\end{array}$ & $\begin{array}{c}\text { Cd Concentration } \\
(\mathrm{mg} / \mathrm{kg})\end{array}$ \\
\hline Liver & $3.17 \pm 2.39$ & $3.47 \pm 3.19$ \\
Muscles & BDL & $0.14 \pm 0.04$ \\
Kidney & BDL & $0.93 \pm 0.43$
\end{tabular}

Where BDL is below detectable limit

The concentrations of $\mathrm{Pb}$ and $\mathrm{Cd}$ present in the liver and kidney samples (Table 2) were higher than in muscles. This can be attributed to the fact that since the main organs for detoxification and filtering of harmful compounds in living organisms are the liver and the kidney, they would record higher levels of these heavy metals than in other body parts (Okoye \& Ihedioha, 2010; Adzitey et al., 2015). According to the EFSA (2009), the ability of a heavy metal to be highly concentrated in the tissues of a living organism will depend on the metabolism efficiency of its organ systems.

The liver samples of sheep and cattle recorded the highest concentration of $\mathrm{Cd}$ and $\mathrm{Pb}$, respectively. The high concentrations of $\mathrm{Cd}$ and $\mathrm{Pb}$ recorded in the liver could be attributed to the agricultural activities through the application of phosphate fertilizers which are known to contain heavy metals such as Cadmium, Lead, and Arsenic, thereby contaminating the feed of the animals (Pan et al., 2010). It could also be as a result of the feeding pattern or heavy metal contamination of the environmental media (air, water, and soil) at the feeding grounds of the animals which are very essential for their survival. Again, factors such as the fat content, the age, the sex and mostly the size of the animals which were not considered in this study could account for these high concentrations (Alonso et al., 2000).

In the Northern Region of Ghana, there is a traditional way of managing livestock on an open- range system. This gives way for the grazing animals to pick up heavy metals-contaminated food as they feed in the open agricultural fields, waste dumps, polluted water sources, and are as well exposed to emissions from various combustion sources (Okoye \& Ihedioha, 2010). It has been reported that higher concentrations of heavy metals taken into the human body via the ingestion of infected animals can cause a reduction in growth, a lower production of milk and miscarriages in women (National Research Council, 2005).

A comparison was done between the average concentrations of $\mathrm{Pb}(1.06 \mathrm{mg} / \mathrm{kg})$ recorded in this study and the permissible limits indicated by the WHO $(0.01 \mathrm{mg} / \mathrm{kg})$ and the UESEPA $(0.015 \mathrm{mg} / \mathrm{kg})$. Also, for $\mathrm{Cd}(1.51 \mathrm{mg} / \mathrm{kg})$, a comparison was done with the permissible limits indicated by the WHO $(0.03 \mathrm{mg} / \mathrm{kg})$ and the USEPA $(0.05 \mathrm{mg} / \mathrm{kg})$. It was identified that the levels of $\mathrm{Pb}$ and $\mathrm{Cd}$ recorded in the study were higher than the permissible limits proposed by the regulatory bodies, therefore posing an environmental health concern. 
Table 3 Concentrations of heavy metals in selected organs of sampled animals

\begin{tabular}{llcc}
\hline ANIMAL & ORGANS & Pb $(\mathbf{m g} / \mathbf{k g})$ & $\mathbf{C d}(\mathbf{m g} / \mathbf{k g})$ \\
\hline CATTLE & LIVER & $7.06 \pm 7.06 \mathrm{a}$ & $0.05 \pm 0.02 \mathrm{a}$ \\
KIDNEY & BDL & $0.26 \pm 0.14 \mathrm{a}$ \\
MUSCLE & BDL & $0.07 \pm 0.03 \mathrm{a}$ \\
SHEEP & LIVER & $2.46 \pm 2.46$ & $9.99 \pm 9.50 \mathrm{~b}$ \\
& KIDNEY & BDL & $2.30 \pm 0.91 \mathrm{~b}$ \\
GOAT & MUSCLE & BDL & $0.21 \pm 0.06 \mathrm{~b}$ \\
& LIVER & BDL & $0.37 \pm 0.02 \mathrm{c}$ \\
& KIDNEY & BDL & $0.23 \pm 0.05 \mathrm{c}$ \\
\cline { 2 - 4 } & MUSCLE & BDL & $0.13 \pm 0.08 \mathrm{c}$
\end{tabular}

Where BDL is below detectable limit

According to the human health risk assessment conducted, it was revealed that the average daily dose (ADD) for $\mathrm{Pb}$ and $\mathrm{Cd}$ in all samples were all below $10^{-6}$. For $\mathrm{Pb}$, an $\mathrm{ADD}$ value ranging from $7.64 \times 10^{-9}-2.19 \times 10^{-8}$ and $3.27-9.35 \times 10^{-9}$ were recorded for children and adult groups respectively, while the ADD values for Cd ranged from $1.96-4.57 \times 10^{-6}$ and $1.13-2.63 \times 10^{-7}$ for children and adult groups respectively (Table 4). The result obtained implied a very low risk of carcinogenicity for the population which purchased meat from the abattoir as Hu et al. (2012) indicates that carcinogenicity of heavy metals can only occur when the product of the ADD and Slope Factor is greater than or equal to $10^{-6}$ and is only applicable to $\mathrm{Pb}$ contaminants.

Table 4 Calculated average daily dose intake (ADD) and Cancer risks of Cadmium (Cd) and Lead (Pd) in Children and Adult

\section{Cancer risk for children and adults}

\begin{tabular}{|c|c|c|c|c|c|c|c|c|}
\hline \multirow[t]{3}{*}{ Animal } & \multicolumn{4}{|c|}{ Lead $(\mathrm{Pb})$} & \multicolumn{4}{|c|}{ Cadmium (Cd) } \\
\hline & \multirow[t]{2}{*}{$\mathrm{ADD}$} & \multirow[t]{2}{*}{ SF } & \multicolumn{2}{|c|}{ Risk } & \multirow[t]{2}{*}{ ADD } & \multirow[t]{2}{*}{ SF } & \multicolumn{2}{|c|}{ Risk } \\
\hline & & & Children & Adult & & & Children & Adult \\
\hline Cattle & $2.35 \mathrm{mg} / \mathrm{kg}$ & $8.5 \times 10^{-3}$ & $2.19^{\times} 10^{-8}$ & $9.35^{\times} 10^{-9}$ & - & - & - & - \\
\hline Sheep & $0.82 \mathrm{mg} / \mathrm{kg}$ & $8.5 \times 10^{-3}$ & $7.64 \times 10^{-9}$ & $3.27 \times 10^{-9}$ & $4.17 \mathrm{mg} / \mathrm{kg}$ & 15 & $4.57^{\times} 10^{-6}$ & $1.96^{\times} 10^{-6}$ \\
\hline Goat & - & - & - & - & $0.24 \mathrm{mg} / \mathrm{kg}$ & 15 & $2.63^{\times} 10^{-7}$ & $1.13^{\times} 10^{-7}$ \\
\hline
\end{tabular}




\section{Conclusion}

Amongst the body parts analysed, liver had the highest concentration of heavy metals, followed by kidneys and then muscles. The highest concentration of $\mathrm{Pb}$ was found in cattle, while that of $\mathrm{Cd}$ was in sheep. Singeing activities, contaminated feed and poor meat hygiene were considered the major possible sources for metal contamination in processed meat. The meat sampled had no risk of carcinogenicity, since they were below the permissible limits proposed by regulatory bodies, but going forward, as a need for environmental health concern, it will be essential to periodically monitor how meat is processed as well as the levels of potential heavy metals present in the processed meat.

\section{Acknowledgement}

The team is very grateful to the workers in the Tamale Abattoir for their immense consent and support during the sampling. We are also grateful to the Central Laboratory of KNUST for the analysis.

\section{References}

Arora, M., Kiran, B., Rani, S., Rani, A., Kaur, B. \& Mittal, N. (2008). Heavy metal accumulation in vegetables irrigated with water from different sources. Food Chem., 11:811-815.

Adzitey, F., Kumah, A. \& Mensah, S. B. K. (2015). Assessment of the presence of selected heavy metals and their concentration levels in fresh and grilled beef/guinea fowl meat in the Tamale Metropolis, Ghana. Research Journal of Environmental sciences, 9(3):152-158. doi:10.3923/rjes.2015.152.158.

Akan, J. C., Abdulrahman, F. I., Sodipo, O. A. \& Chiroma, Y. A. (2010). Distribution of heavy metals in the liver, kidney and meat of beef, muttons, caprine and chicken from Kasuwan Shanu Market in Maiduguri Metropolis, Borno State. Research Journal of Applied Sciences Engineering and Technology, 2 (8):743-748.

Alonso, M. L., Benedito, J. L., Miranda, M., Castillo, C., Hernández, J., \& Shore, R. F. (2000). Arsenic, cadmium, lead, copper and zinc in cattle from Galicia, NW Spain. Science of the Total Environment, 246(2-3): 237-248. https://doi.org/10.1016/S00489697(99)00461-1

Baykov, B. D., Stoyanov, M. P. \& Gugova, M. L. (1996). Cadmium and Lead bioaccumulation in male chickens for high food concentrations. Toxicological and Environmental Chemistry, 54(1-4): 155- 159.

Brito, G., Díaz, C., Galindo, L., Hardisson, A., Santiago, D. \& Montelongo, F. G. (2005). Levels of metals in canned meat products: Intermetallic correlations. Bulletin of Environmental Contamination and Toxicology, 44 (2): 309-316.

Chakraborty, S., Dutta, A., Sural, S., Gupta, D. \& Sen, S. (2013). Ailing bones and failing kidneys: a case of chronic cadmium toxicity. Annals of Clinical Biochemistry, 50(5): 492 495. doi: $10.1177 / 0004563213481207$.

Ekanma, K. N. J. \& Ottah, A. A. (2015). Determination of the presence and concentration of heavy metal in Cattle Hides singed in Nsukka abattoir. J. Vet. Med. Anim. Hlth, 7(1): 9-17.

European Food Safety Authority (2009). Panel on contaminants in the food chain: Cadmium in food. The EFSA Journal, 980:1-139.

Khalufalla, F. A., Ali, F. H., Schwagele, F. \& AbdEl-Wahab, M. A. (2011). Heavy metal residue in beef carcasses in Beni - Seuf abattoir, Egypt. Vet Ital, 47(3): 351-361.

Gašparík, J., Binkowski, Ł. J., Jahnátek, A., Šmehýl, P., Dobiaš, M., Lukáč, N., Błaszczyk, M., Semla, M., \& Massanyi, P. (2017). Levels of Metals in Kidney, Liver, and Muscle Tissue and their Influence on the Fitness for the Consumption of Wild Boar from Western Slovakia. Biological Trace Element 
Research, $\quad$ 177(2): 258-266. https://doi.org/10.1007/s12011-016-0884-z

Ghana Statistical Service (GSS) (2014). District Analytical Report Tamale Metropolis: Population and housing census, 2010. https://www.statsghana.gov.gh

Hu, X., Zhang, Y., Ding, Z., Wang, T., Lian, H., Sun, Y. \& Wu, J. (2012). Bioaccessibility and health risk of arsenic and heavy metals $(\mathrm{Cd}$ $\mathrm{Co}, \mathrm{Cr}, \mathrm{Cu}, \mathrm{Ni}, \mathrm{Pb}, \mathrm{Zn}$ and $\mathrm{Mn}$ ) in TSP and PM2.5 in Nanjing, China. Atmospheric Environment, 57:146-152. doi.org/10.1016/j.atmosenv.2012.04.056.

Hussain, K., Rahman, M., Prakash, A. \& Hoque, R. R. (2015). Street dust bound PAHs, carbon and heavy metals in Guwahati citySeasonality, toxicity and sources. Sustainable Cities and Society, 19:17-25. doi.org/10.1016/j.scs.2015.07.010.

Hussain, R. T., Ebraheem. M. K. \& Moker, H. M. (2012). Assessment of heavy metals (Cd, Pb and $\mathrm{Zn}$ ) contents in livers of chicken available in the local markets of Basrah City, Iraq. Basrah J.Vet.Res. 11:43-51.

Joint FAO/WHO Expert Committee on Food Additives (2003). World Health Organisation \& Food and Agriculture Organisation of the United Nations. Evaluation of certain food additives and contaminants: sixty-first report of the Joint FAO/WHO Expert Committee on Food Additives. Geneva: World Health Organisation.

http://www.who.int/iris/handle/10665/42849.

Kalu, E., Nwanta, J. A. \& Anaga, A. O. (2015). Determination of the presence and concentration of heavy metal in cattle hides singed in Nsukka abattoir. J. Vet. Med. Anim. Hlth., $\quad 7(1)$ : 9-17. doi: 10.5897/JVMAH2014.0283
Khalufalla, F. A., Fatima, H., Ali, F. M. \& Abd-El, W. (2011). Heavy metal residue in beef carcasses in Beni-Seuf abattoir, Egypt. Veterinaria ltaliana, 47 (3):351-361.

Lee-Steere, C. (2009). Environmental risk assessment guidance manual for industrial chemical. Australian Environment Agency Pty Ltd, Commonwealth of Australia.

Lukáčová, A., Golian, J., Massanyi, P. \& Formicki, G. (2014). Lead concentration in meat and meat product of Different Origin. Potravinarstvo Slovak Scientific Journal for Food Industry, 8 (1): 43-47.

Martin, S. \& Griswold, W. (2009). Human health effects of heavy metals. Environmental science and Technology Brief for citizens, 15:1-6.

National Research Council (2005). Mineral tolerance of animals ( $2^{\text {nd }}$ ed.). Washington, DC: The National Academies Press. doi.org/10.17226/11309.

Nkansah, M. A. \& Ansah, J. K. (2014). Determination of $\mathrm{Cd}, \mathrm{Hg}, \mathrm{Cr}$ and $\mathrm{Pb}$ levels in meat from the Kumasi central abattoir. International journal of scientific and research publication, 4 (8):1-3.

Obiri-Danso, K., Hogarh, J. \& Antwi-Agyei, P. (2008). Assessment of contamination of singed hides from cattle and goats by heavy metals in Ghana. African Journal of Environmental Science and Technology, 2:217-221

Okiei, W., Ogunlesi, M., Alabi, F., Osiaghwu, B. \& Sojinrin, A. (2009). Determination of toxic metal concentration in flame treated meat products, ponmo. Afr. J. Biochem. Res., 3 (10):332-339.

Okoye, C. O. B. \& Ihedioha, J. N. (2010). Impact of environmental cadmium, lead, copper and zinc on quality of goat meat in Nigeria. 
Bulletin of the chemical society of Ethiopia, 24

doi:10.4314/bcse.v24i1.52975

Pan, J., Plant, J. A., Voulvoulis, N., Oates, C. J. \& Ihlenfeld. C. (2010). Cadmium levels in Europe: implications for human health. Environ. Geochem. Health, 32:1-12.

Rowland, A. S. \& McKinstry, R. C. (2006). Lead toxicity. White matter lesions, and aging. Neurology, 66:1464-1465.

Sabir, S. M., Khan, S. W. \& Hayat, I. (2003). Effect of environmental pollution on quality of meat in district Bagh, Azad Kashmir. Pak. J. Nutr., 2 (2):98-101.

Santhi, D., Balakrishnan, V., Kalaikannan, A. \& Radhakrishnan, K. T. (2008) Presence of heavy metals in pork products in Chennai (India). Am. J. Food Technol., 3 (3):192-199.

Sedki, A., Lekouch, N., Gamon, S., Pineau, A. (2003). Toxic and essential trace metals in muscles, kidney and liver of bovines from a polluted area of Morrocco. Science of the Total Environment, 317 (1-3):201-205. doi:10.1016/S0048-9697(03)00050-0

Smolders E. \& Six L. (2013). Revisiting and updating the effect of phosphate fertilizers to cadmium accumulation in European agricultural soils. KU Leuven, Division Soil and Water Management Kasteelpark Arenberg 20, 3001 Heverlee, Belgium

Ubwa, S. T., Ejiga. R., Okoye, P-A. C. \& Amua, Q. M. (2017). Assessment of heavy metals in the blood and some selected entrails of cattle, goat, d pig slaughtered at Wurukum Abattoir, Makurdi-Nigeria. Advances in analytical chemistry, 7(1):7-12. doi:10.5923/j.aac. 20.70701.02.

USEPA IRIS (2011). US Environmental Protection Agency's integrated risk information system. Environmental Protection Agency region I,
Washington $\quad$ DC 20460. http://www.epa.gov/iris/

Wongsasuluk, P., Chotpantarat, S., Siriwong, W. \& Robson, M. (2014). Heavy metal contamination and human health risk assessment in drinking water from shallow groundwater wells in an agricultural area in Ubon Ratchathani province, Thailand. Environ Geochem Health, 36:169-82.

World Health Organisation (1997). Aluminium. Geneva, World Health Organization, international programme on chemical safety (Environmental Health Criteria 194).

Ying, L., Shaogang, L. \& Xiaoyang, C. (2016). Assessment of heavy metal pollution and human health risk in urban soils of a coal mining city in East China. Human and Ecological Risk Assessment: An International Journal, 22:1359-1374. doi.org/10.1080/10807039.2016.1174924 